\title{
The Scale of Happiness Strategies for Children's used by Preschool Teachers
}

\author{
Ayça Bahar BAKKALOĞLU 1(D), Ali ERYILMAZ2 (iD Özkan SAPSAĞLAM*3(D) \\ 1 Ministry of Education, İstanbul, Turkey, baharbakkaloglu@gmail.com \\ 2 Yildiz Technical University, Education Faculty Department of Psychological Counseling, İstanbul, Turkey, erali76@hotmail.com \\ ${ }^{3}$ Yıldız Technical University, Education Faculty Department of Psychological Counseling, İstanbul, Turkey, ozkaanim@gmail.com \\ * Corresponding Author: ozkaanim@gmail.com
}

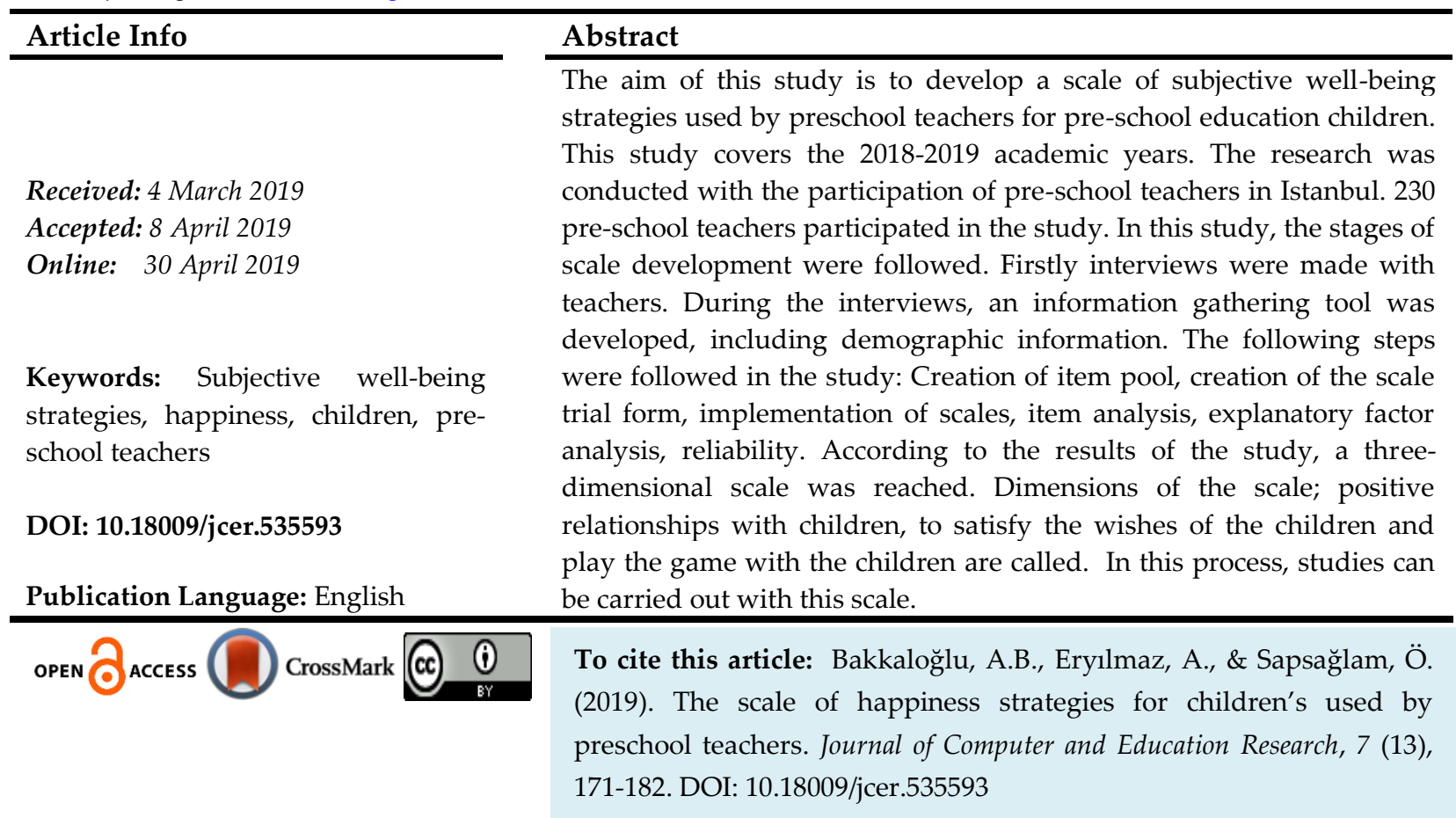

\section{Introduction}

Pre-school period is a very important period in the development of children. This period refers to critical years in terms of gaining basic knowledge, skills and habits to children (Akgün, Yarar \& Dinçer, 2011; Amca \& Kıvanç-Öztuğ, 2016; Sapsağlam, 2016a). Preschool experiences provide important contributions to the child's personality and socialization processes (Yumuş, 2013). The effect and role of early childhood education on the lives of children and their families are increasing rapidly throughout the world (Lee \& Hayden, 2009). Pre-primary education institutions are the first educational institution encountered by the child and the preschool teachers are the first teachers in the life of the child and have a significant impact on the child (Sapsağlam, 2016b). Teachers are laying the foundations for the future happiness of the child with their positive effects on their students (Bilgin-Aydın, 2003). The preschool teacher is the most important factor in the education process and the quality of pre-school education is the same as the quality of the teacher (Barnett, 2003). 
Children's mental health should be handled according to constantly changing and evolving mental, physical and social competencies, critical periods and environmental factors in these critical periods (Seven, 2018). The American National Association for Mental Health (ANSM), in accordance with the age of children with mental health facilities; open and healthy thinking, appropriate social development, to learn new skills, self-confidence, healthy emotional stresses should be emphasized (Palut, 2001). The child forms the first spiritual structure that forms the basis of his/her personality at the age of 0-6. Persons who will make the child feel that he/she is an individual and that will be the first building blocks of his/her personality are the parents and then the other members of the family (BilginAydın, 2003). Happiness, which is one of the basic feelings that children realize first, is considered as a positive indicator, determinant, direction transmitter and output of their development (Demiriz \& Ulutaş, 2016). Happiness is based on common sense, life satisfaction, pleasure-based and perceived desire satisfaction (Eryılmaz, 2016).

The increase in the level of happiness of children provides positive and positive interaction with the people around them. The feeling of happiness should be strong in terms of being able to look at life positively and feed hope in the first years of life (Demiriz \& Ulutaş, 2016). In the pre-school period, children experience the first institutional experience and spend their whole day without a break with an adult (teacher) for the first time in addition to his / her family and his / her immediate surroundings (Akgün, Yarar, \& Dinçer, 2011). Therefore, teachers are also among the people responsible for the happiness of children in the first childhood of 2-6 years (Eryllmaz, 2016). From this point of view, the strategies used by the teachers to make their students happy in the preschool period are worth researching.

Decrease in happiness and life satisfaction of children can lead to problems such as decrease in academic achievement, weakening of friendship relations, loneliness, depression and drug addiction (Yucel \& Vogt Yuan, 2015). Increasing children's happiness supports the child in vital skills such as self-realization, positive relations with other people and success (Bird \& Markle, 2012). Today, happiness education courses are given in different countries of the world. For example, a happiness education program has been implemented for children between 3-5 years of age in Korea since 2013 (Ministry of Education, 2013).

When the literature on developing a measurement tool for pre-school age children is examined, the scale of happiness increase strategies used by mothers with 1-5 years old 
children (Eryılmaz \& Sapsağlam, 2018), anxiety level scale for preschool children (Güngör \& Buluş, 2016), scale of parental opinions (Özyürek, 2017), the scale of beliefs of parents about children's emotions (Kılıç \& Kumandaş, 2017), pre-school social skills assessment scale (Ömeroğlu et al., 2014), pre-school acceptance scale (Ahmetoğlu, Sphendi \& Acar, 2018), scale of determining the philosophical attitudes and behaviors of preschool children (Dirican \& Deniz, 2017), communication skills scale for pre-school age children (Ergin, 2004), behavior scale for preschool children (Özbey \& Alisinanoğlu, 2009), there is no scale development study for the strategies they use to make their students happy. While there are studies on subjective well-being strategies of adults and adolescents (Eryılmaz, 2010, 2015, 2017), there are very few studies conducted on preschool children (Eryılmaz \& Sapsağlam, 2018). It is thought that this study is important because it contains a measurement tool on a subject not yet studied in the literature and will contribute to the literature.

\section{Method}

\section{Research Design}

The aim of this study was to develop a scale of subjective well-being strategies used by preschool teachers for pre-school children. The study was conducted in the relational screening model. The study was conducted in the context of scale development. The following steps were followed in the study: Creation of item pool, creation of the scale trial form, implementation of scales, item analysis, explanatory factor analysis, reliability. In this study, the stages of scale development were followed. Firstly, interviews were made with teachers. During the interviews, an information gathering tool was developed, including demographic information. In this tool, the question "What are you doing to make happy children in your class" was asked. Sentence based content analysis method was applied to the answers given to this question. As a result of this application a pool of 30 items was created.

The items formed were converted to scale pretest forms. In the area of scale development, two experts (with a doctorate degree) were evaluated in terms of the appropriateness, clarity and clarity of the items. As a result of the evaluation, 10 items were excluded and 20 items were included in the scale trial form. These 20 items were applied to 230 preschool teachers. 
Bakkaloğlu, Eryılmaz \& Sapsağlam

The scales filled by the teachers were transferred to the electronic environment for statistical analysis. First of all, item analysis was performed based on 27\% lower and upper group criterion. After item analysis, exploratory factor analysis was performed with the Upright Rotation Method. Then, reliability analysis of the scale was performed based on the internal consistency method. Finally, the validity analysis of the scale was made by the Positive Teacher Scale.

\section{Instruments}

In order to examine the criterion-based validity of the scale developed in the study, Positive Teacher Scale (Eryllmaz \& Bek, 2018) was used. This scale consists of five dimensions and 21 items. In the construct validity study conducted on the basis of both exploratory and confirmatory factor analysis, it was found that the scale gave good fit values. The explained variance of the scale was $63.230 \%$. The reason for using the Positive Teacher Scale is that positive teachers are teachers who produce positive emotions in students. Strategies for increasing happiness are also used by teachers. The use of strategies makes children happy. As a result, teachers using strategies are expected to have positive teacher characteristics.

\section{Study Group}

This study covers the 2018-2019 academic years. The research was conducted with the participation of pre-school teachers in Istanbul. 230 pre-school teachers participated in the study. The demographic status of the teachers participating in the research is: 224 (97.4\%) of the teachers were female and $6(2.6 \%)$ were male. The number of teachers between the ages of 25 and under age was $91(39,6 \%)$, the number of teachers in the 26-35 age group was 98 $(42,6 \%)$, the number of teachers in the $36-45$ age group was $33(14,3 \%)$ and $46-55$. The number of teachers in the age range is 8 (3.5\%). Of the teachers participating in the study, 95 (41.3\%) were employed in the official preschool education institution and $135(58.7 \%)$ in the private pre-school education institution.

\section{Findings}

In this part of the study, first item analysis results are given. Then, the results of factor analysis were discussed. Then, the findings related to reliability analysis were mentioned. Finally, the findings of the validity analysis are presented. 
Table 1. Results of item analysis

\begin{tabular}{|c|c|c|c|c|c|}
\hline & Group & $\mathrm{n}$ & $\mathrm{M}$ & SD & $\mathrm{t}$ \\
\hline \multirow[t]{2}{*}{ M1 } & 1,00 & 61 & 4,0984 & 81045 & $-7,164^{* *}$ \\
\hline & 2,00 & 61 & 4,9063 & ,38704 & \\
\hline \multirow[t]{2}{*}{ M2 } & 1,00 & 61 & 4,0000 & ,48305 & $-13,245^{* *}$ \\
\hline & 2,00 & 61 & 4,9219 & 27049 & \\
\hline \multirow{2}{*}{ M3 } & 1,00 & 61 & 3,8033 & ,40082 & $-20,159^{* *}$ \\
\hline & 2,00 & 61 & 4,9531 & 21304 & \\
\hline \multirow[t]{2}{*}{ M4 } & 1,00 & 61 & 3,4918 & 62244 & $-18,241^{* *}$ \\
\hline & 2,00 & 61 & 4,9688 & ,17537 & \\
\hline \multirow[t]{2}{*}{ M5 } & 1,00 & 61 & 3,5082 & 62244 & $-11,100^{* *}$ \\
\hline & 2,00 & 61 & 4,6406 & ,51539 & \\
\hline \multirow[t]{2}{*}{ M6 } & 1,00 & 61 & 3,9180 & 27659 & $-27,993^{* *}$ \\
\hline & 2,00 & 61 & 4,9844 & 12500 & \\
\hline \multirow[t]{2}{*}{ M7 } & 1,00 & 61 & 3,3443 & ,96411 & $-11,598^{* *}$ \\
\hline & 2,00 & 61 & 4,8438 & ,36596 & \\
\hline \multirow[t]{2}{*}{ M8 } & 1,00 & 61 & 2,9508 & 1,08668 & $-13,177^{* *}$ \\
\hline & 2,00 & 61 & 4,8594 & 39308 & \\
\hline \multirow[t]{2}{*}{ M9 } & 1,00 & 61 & 2,9508 & ,86460 & $-10,466^{* *}$ \\
\hline & 2,00 & 61 & 4,4063 & 68357 & \\
\hline \multirow[t]{2}{*}{ M10 } & 1,00 & 61 & 3,5902 & 61582 & $-14,377^{* *}$ \\
\hline & 2,00 & 61 & 4,9063 & ,38704 & \\
\hline \multirow[t]{2}{*}{ M11 } & 1,00 & 61 & 3,3115 & ,59276 & $-17,109^{* *}$ \\
\hline & 2,00 & 61 & 4,8750 & ,41786 & \\
\hline \multirow[t]{2}{*}{ M12 } & 1,00 & 61 & 4,1148 & ,81850 & $-5,136^{* *}$ \\
\hline & 2,00 & 61 & 4,7188 & ,45316 & \\
\hline \multirow[t]{2}{*}{ M13 } & 1,00 & 61 & 3,9344 & ,44230 & $-18,245^{* *}$ \\
\hline & 2,00 & 61 & 4,9844 & ,12500 & \\
\hline \multirow[t]{2}{*}{ M14 } & 1,00 & 61 & 3,8197 & 38765 & $-22,827^{* *}$ \\
\hline & 2,00 & 61 & 4,9844 & 12500 & \\
\hline \multirow[t]{2}{*}{ M15 } & 1,00 & 61 & 3,7377 & ,44353 & $-21,608^{* *}$ \\
\hline & 2,00 & 61 & 4,9844 & 12500 & \\
\hline \multirow[t]{2}{*}{ M16 } & 1,00 & 61 & 4,0000 & ,44721 & $-16,083^{* *}$ \\
\hline & 2,00 & 61 & 4,9688 & ,17537 & \\
\hline \multirow[t]{2}{*}{ M17 } & 1,00 & 61 & 3,5410 & 64740 & $-17,004^{* *}$ \\
\hline & 2,00 & 61 & 4,9688 & 17537 & \\
\hline \multirow[t]{2}{*}{ M18 } & 1,00 & 61 & 3,5082 & 78789 & $-14,797^{* *}$ \\
\hline & 2,00 & 61 & 4,9844 & ,12500 & \\
\hline \multirow[t]{2}{*}{ M19 } & 1,00 & 61 & 3,4098 & ,88274 & $-14,124^{* *}$ \\
\hline & 2,00 & 61 & 4,9844 & 12500 & \\
\hline \multirow[t]{2}{*}{ M20 } & 1,00 & 61 & 4,0492 & 66899 & $-6,579 * *$ \\
\hline & 2,00 & 61 & 4,7188 & ,45316 & \\
\hline
\end{tabular}

Table 1 shows the results of item analysis. According to the results of the item analysis conducted based on the technique of upper and lower group of $27 \%$, it was found that all of the substances at the level of $\mathrm{p}<0.01$ had high discriminative power.

Findings of explanatory factor analysis

The sample group included in the study should have a sufficiently large sampling for exploratory factor analysis. In this study, KMO (Kaiser-Meyer Olkin) and Bartlett Test were performed before exploratory factor analysis. According to the results of the analysis, KMO 
value was 0.823 and the mean value was $2680.452(\mathrm{p}<0.01)$. These findings showed that the sample was large enough for exploratory factor analysis.

Factor analysis was performed based on the method of perpendicular rotation. The four-dimensional structure was $76.44 \%$. However, the items with a small difference between 0.100 and 0.300 factor loadings were excluded from the analysis. The rotation was then continued. Finally, a 12-item and three-dimensional scale was reached.

Table 2. Results of explanatory factor analysis

\begin{tabular}{cccc}
\hline Items & $\begin{array}{c}\text { First } \\
\text { dimension }\end{array}$ & $\begin{array}{c}\text { Second } \\
\text { dimension }\end{array}$ & $\begin{array}{c}\text { Third } \\
\text { dimension }\end{array}$ \\
\hline 1 &, 883 &, 259 &, 252 \\
2 &, 843 &, 166 &, 249 \\
3 &, 798 & & \\
4 &, 775 &, 217 &, 273 \\
5 &, 731 &, 874 & \\
6 &, 123 &, 795 &, 197 \\
7 &, &, 770 &, 722 \\
8 &, 261 &, 719 &, 704 \\
9 & & & \\
10 &, 110 & & \\
11 &, 258 & & \\
12 & & & \\
\hline
\end{tabular}

As a result of factor analysis, a three dimensional structure was reached. The explained variance of this three-dimensional structure was found as $79.203 \%$. The variance explained by the first dimension is $33.32 \%$. The variance explained by the second dimension is $25.827 \%$. The variance explained by the third dimension is $20.057 \%$.

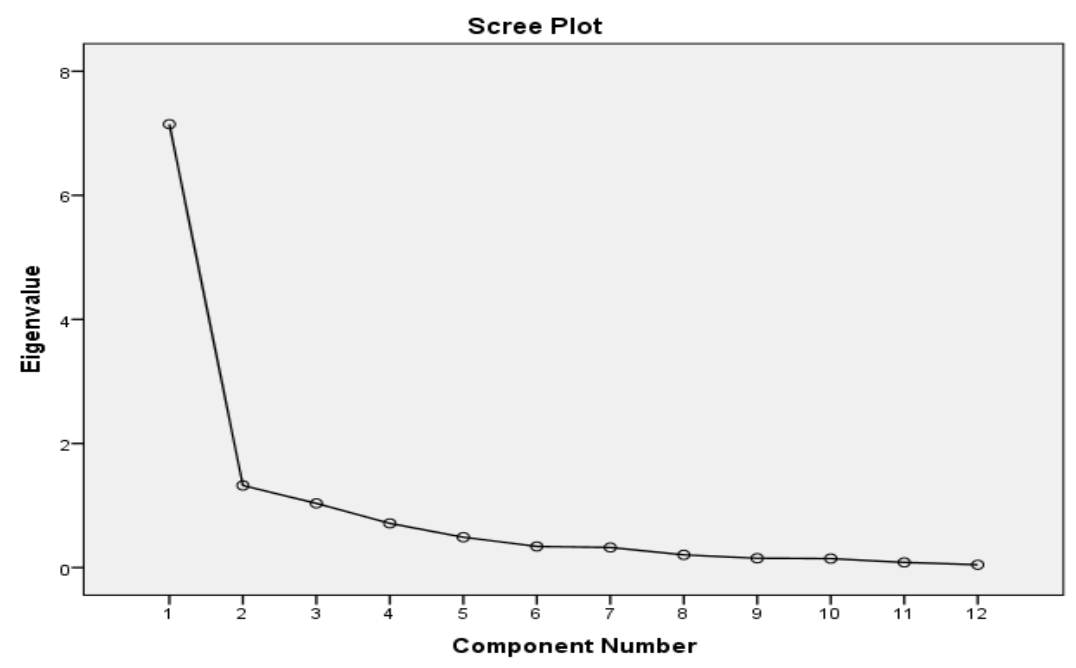

Figure 1. Scatter plot 
The dimensions obtained from the factor analysis are named after the item contents. In this direction, the first dimension of the scale is called "play the games with the children", the second dimension of the scale is called positive relationships with children", the second dimension of the scale is called "to satisfy the wishes of the children". The scale was named as "The Scale of Happiness Strategies for Children Used by Preschool Teachers".

\section{Findings on the Reliability of the Scale}

The reliability of the scale developed in the study was based on internal consistency analysis (Cronbach Internal Coherence Analysis). In this respect, the reliability of the first dimension of the scale was found to be 0.92 . The reliability of the second dimension of the scale was found to be 0.91 . The reliability of the third dimension of the scale was found to be 0.80 . The reliability of the whole scale was found to be 0.93 .

\section{Findings for the Validity of the Scale}

The validity of The Scale of Happiness Strategies for Children Used by Preschool Teachers was examined with Positive Teacher Scale. In this respect, Pearson Correlation Analysis technique was applied. Analysis results are given in Table 3.

Table 3. Pearson correlation

\begin{tabular}{lcc}
\hline \multicolumn{1}{c}{ Variables } & 1 & 2 \\
\hline $\begin{array}{l}\text { 1.Positive teacher } \\
\begin{array}{l}\text { 2. Total point of the scale of happiness strategies for } \\
\text { children used by preschool teachers }\end{array}\end{array}$ & 1 &, $435^{* *}$ \\
\hline
\end{tabular}

\section{Discussion and Conclusions}

The aim of this study is to develop a scale of subjective well-being strategies used by preschool teachers for pre-school education children's. According to the results of the research, "The Scale of Happiness Strategies for Children Used by Preschool Teachers" was reached. Developed scale; there are three important dimensions: Establishing a positive relationship with children, satisfying children's desires and playing games to children.

When the literature is examined, empirical studies (Eryllmaz, 2010, 2012a, 2012b; Eryılmaz \& Sapsağlam, 2018) can be seen in experimental studies aiming to increase happiness (Eryılmaz, 2014a, 2014b; Fordyce, 1983) and theoretical explanations (Buss, 2000). In this regard, it is seen that there are no studies on the strategies used by preschool teachers 
for children. Thus, this study has contributed to the literature because it has been done on a subject that has little work on the literature.

One of the dimensions of the scale developed in this study was named "Playing games with children. When the literature is examined, it is stated that the game is an important tool in the development of the child (Frost, Wortham \& Reifel, 2001). It is even stated that the child's work is to play games (Papalia, Olds \& Feldman, 2007). Especially in preschool education programs, it is stated that play is important and must have free play times (File, 1994). All these information and findings reveal the importance of the game. At this point, the size obtained in the scale is consistent with the literature.

In this study, another dimension of the scale was named as "satisfying children's desires". The strategy of satisfying the requests took place as a strategy in previously developed scale studies (Eryılmaz, 2010; Eryılmaz \& Sapsağlam, 2018). Its involvement in this study points to a common aspect of humanity. According to Ery1lmaz (2016), the strategy to satisfy the wishes represents the hedonic dimension of happiness and has a biological aspect. As a result, we can link the strategy of satisfying the requests in this study to the relationship of the strategy with biological structures.

The final dimension of the scale is called "Positive relation with children". The importance of relationships in people's lives cannot be denied. Human is a relationshiporiented entity (Prager, 1997). Positive relations with students have very important results. For example, as a result of positive relationships with students, students' academic success is increasing and their participation in school and class increases (Roorda, Koomen, Spilt \& Oort, 2011). Positive relationships have positive effects on students' development (Hughes, Cavell \& Willson, 2001). According to Eryilmaz (2014a), the relations of teachers with the children's have an important place in their happiness. All these findings indicate the importance of positive relationships.

\section{Acknowledgement}

This study was prepared from project of Ayça Bahar Bakkaloğlu completed under the counseling of Prof. Dr. Ali Eryılmaz. 


\section{References}

Ahmetoğlu, E., Shpendi, T. \& Acar, İ. H. (2018). Çocukların özel gereksinimli akranlarına karşı tutumları: Okul öncesi kabul ölçeği-yenilenmiş formu (OÖKÖ) uyarlama çalışması [Attitudes of young children towards their peers with disabilities: The adaptation study of the acceptance scale for kindergarten- revised]. Turkish Studies, 12 (18), 1-20.

Akgün, E., Yarar, M. \& Dinçer. Ç. (2011). Okul öncesi öğretmenlerin sınıf içi etkinliklerde kullandıkları sinıf yönetimi stratejilerinin incelenmesi [The evaluation of classroom management strategies of preschool teachers in classroom activities]. Pegem Ĕgitim ve Öğretim Dergisi, 1 (3), 2-9.

Amca, D. \& Kıvanç-Öztuğ, E. (2016). Examination of the social behavior of 4 age old preschool children according to teacher views. Journal of Computer and Education Research, 4 (7), 82-102. DOI: 10.18009/jcer.04260

Barnet, W. S. (2003). Better teachers, better preschols: Student achievement linked to teacher qualifications. NIER Preschol Policy Maters, 2, 1-11.

Bilgin-Aydın H. (2003) Çocuk ruh sağlığı [Child mental health]. İstanbul: Morpa Kültür Yayınları.

Bird, J. M. \& Markle, R. S. (2012). Subjective well-being in school environments: promoting positive youth development through evidence-based assessment and intervention. American Journal of Orthopsychiatry, 82, 61-66.

Buss, D. M. (2000). The evolution of happiness. American Psychologist, 55 (1), 15-23.

Demiriz, S. \& Ulutaş, İ. (2016). Çocuklar ne kadar mutlu? Bazı değişkenlere göre çocuklarda mutluluğun belirlenmesi [How happy are children? Determining happiness according to some variables]. Adnan Menderes Üniversitesi Ĕ̆itim Fakültesi Eğitim Bilimleri Dergisi, 7 (1), 16-24.

Dirican, R. \& Deniz, Ü. (2017). Okul öncesi dönemdeki çocukların felsefi tutum ve Davranışlarını belirleme kontrol listesi: geçerlik ve güvenirlik çalışması [Checklist for determining philosophical attitudes and behaviors of preschool children: Validity and reliability study]. Turkish Studies, 12 (14), 137-150.

Ergin, H. (2004). Okul öncesi dönem çocukları için iletişim becerileri ölçeklerinin geçerlik, güvenirlik ve norm çalışması [The validity, reliability and norms of communication skills scales for pre-school children]. Hasan Âli Yücel Ĕ̈itim Fakültesi Dergisi, 1 (2), 181199.

Eryılmaz, A. (2010). Developing a scale about subjective well being increases strategies for adolescents. Journal of Turkish Psychological Counseling, 33, 81-88.

Eryılmaz, A. (2012a). A model of subjective well-being for adolescents in high school. Journal of Happiness Studies, 13 (2), 275-289.

Eryılmaz, A. (2012b). Mental control: how do adolescents protect their subjective well-being. The Journal of Psychiatry and Neurological Sciences, 25 (1), 27-34. 
Eryılmaz, A. (2014a). Üniversite öğrencileri için geliştirilen öznel iyi oluşu artırma Programinın etkililiğinin incelenmesi [Investigating the effectiveness of subjective well-being increasing program for university students]. Mehmet Akif Ersoy Üniversitesi Eğitim Fakültesi Dergisi, 31, 111-128.

Eryllmaz, A. (2014b). Strategies adopted by Turkish adults for increasing happiness in daily life. Mental Health, Religion \& Culture, 17(7), 680-689.

Eryılmaz, A. (2015). Investigation of the relations between religious activities and subjective well-being of high school students. Educational Sciences: Theory and Practice, 15(2), 433444 .

Eryılmaz, A. (2016). Herkes için mutluluğun başucu kitabı: Teoriden uygulamaya pozitif psikoloji [Bedside book of happiness for everyone: Positive psychology from theory to practice]. Ankara: Pegem Akademi.

Eryılmaz, A. (2017). Yetişkinler için mutluluğu artırma stratejileri ölçeğinin geliştirilmesi [Development of happiness increasing strategies scale for adults]. Journal of Mood Disorders, 7 (2), 116-123.

Eryılmaz, A. \& Bek, H. (2018). Pozitif öğretmen ölçeği öğretmen formunun geliştirilmesi [Development of the positive teacher scale from the perspective of teachers]. Kastamonu Education Journal, 26 (4), 1297-1306.

Eryılmaz, A. \& Sapsağlam, Ö. (2018). Development of subjective well-being increasing strategies scale for children (1-5 ages) their mothers use. Journal of Education and Training Studies, 6 (6), 77-83.

Frost, J. L., Wortham, S. C., \& Reifel, R. S. (2001). Play and child development. Merrill, Prentice Hall.

File, N. (1994). Children's play, teacher-child interactions, and teacher beliefs in integrated early childhood programs. Early Childhood Research Quarterly, 9 (2), 223-240.

Fordyce, M. W. (1983). A program to increase happiness: Further studies. Journal of Counseling Psychology, 30 (4), 483-498.

Güngör, H. \& Buluş, M. (2016). Ebeveyn mükemmeliyetçiliğinin 5-6 yaş okul öncesi dönem çocuklarının algılanan kaygı düzeyini öngörmedeki rolü [The role of parent perfectionism on predicting anxiety level of 5 and 6 years old preschool children]. PAU Eğitim Fakültesi Dergisi, 39, 147-159.

Kılıç, Ş. \& Kumandaş, H. (2017). Anne-babaların çocukların duyguları hakkındaki inanışları ölçeğinin geçerlilik ve güvenilirlik çalışması [Turkish validation of the parents' beliefs about children's emotions questionnaire]. Anadolu Psikiyatri Dergisi, 18 (2), 169-178.

Lee, Y. \& Hayden, M. (2009). Early childhood care and education: Worldwide challenges and progresses. Current Issues in Comparative Education, 11, 3-5.

Ministry of Education (2013). Nuri curriculum for 3, 4 year olds. Seoul: Ministry of Education.

Ömeroğlu E, Büyüköztürk, Ş., Çakan, M., Aydoğan, Y., Özyürek, A., Akduman, G. G. ve diğ. (2014). Okul Öncesi Sosyal Beceri Değerlendirme Ölçeği Anne-Baba Formuna Ait Norm Değerlerinin Belirlenmesi ve Yorumlanması [Identification and interpretation of the norm values regarding the parent form of pre-school social skills rating scale]. Karabük Üniversitesi Sosyal Bilimler Enstitüsü Dergisi 4 (2), 102-115. 
Özbey, S. \& Alisinanoğlu, F. (2009). Okul öncesi eğitim kurumuna devam eden 60-72 aylık çocukların problem davranışlarının bazı değişkenlere göre incelenmesi [A study on problem behavior of 60-72 months children who attending public early childhood education institution]. Uluslararası Sosyal Araştırmalar Dergisi, 2 (6), 493-516.

Özyürek, A. (2017). Okul öncesi çocuğa sahip anne-babalara yönelik "çocuk yetiştirmeye ilişkin anne-baba görüşleri ölçeği" ve "anne-baba tutum ölçeği" geliştirme çalışması [A study on developing "parent views on raising children scale" and "parent attitudes scale" for parents with preschool children]. Uluslararası Erken Çocukluk Eğitimi Çalışmaları Dergisi, 2 (1), 26-38.

Palut, B. (2001). Çocuk ruh sağlığı ve rehberlik [Child mental health and counseling]. Abant İzzet Baysal Üniversitesi Ĕ̆itim Fakültesi Dergisi, 1 (2), 57-79.

Papalia, D. E., Olds, S.W., \& Feldman, R. D. (2007). Human development. Boston: McGraw Hill.

Prager, K. J. (1997). The psychology of intimacy. New York: Guilford Press.

Sapsağlam, Ö. (2016a). Okul Öncesi eğitim programlarında yer alan hedeflerin değerler açısından incelenmesi [Examination of targets in preschool education programs in terms of values]. Turkish Studies, 11 (9), 683-700.

Sapsağlam, Ö. (2016b). Okul öncesi dönemde karakter ve değerler eğitimi: Teoriden uygulamaya [Character and values education at preschool: From theory to practise] (Edit. Prof. Dr. Esra Ömeroğlu). Ankara: Pegem Akademi Yayıncılık.

Seven, S. (2018). Çocuk ruh sağlığı [Child mental health]. Ankara: Pegem Akademi.

Yucel, D. \& Vogt Yuan, A. S. (2016). Parents, siblings, or friends? exploring life satisfaction among early adolescents. Applied Research Quality Life, 11, 399-423.

Yumuş, M. (2013). Okul öncesi eğitimcilerinin 36-72 ay aralı̆̆ındaki çocukların davranış problemleri ile ilgili görüşlerinin incelenmesi ve başa çıkma stratejilerinin belirlenmesi [Research on opinions of preschool teachers about behavioral problems of 36-72 month-old children and determining coping strategies]. Yüksek Lisans Tezi, Hacettepe Üniversitesi Sağlık Bilimleri Enstitüsü, Ankara [Master Thesis Hacettepe University, Institute of Health Sciences, Ankara]. 
Below are the expressions made to make your students happy. Please make your assessment of the intensity of the strategies in each statement from the previous week to the present.

First Dimension: Positive relationships with children $(1,2,3,4)$

Second Dimension: Satisfy the desires of the children $(5,6,7)$

Third Dimension: Play the games with the children $(8,9,10,11,12)$

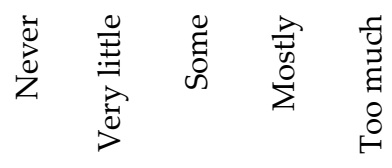

1- To make my students happy; I told them good words.

2- To make my students happy, I made them feel they were valuable.

3- To make my students happy; I gave them praise speeches in class.

4- To make my students happy; I listened to them.

5- To make my students happy; from time to time I did surprises.

6- To make my students happy; I did activities that enjoyed to them.

7- To make my students happy; I gave them their favorite cookies and desserts.

8- To make my students happy; I played the games they loved with them.

9- To make my students happy; I played their favorite games.

10- To make my students happy; I participated in their game activities

11- To make my students happy; I danced with them.

12- To make my students happy; I prepared musical activities.

Aşağıda öğrencilerinizi mutlu etmek için yaptıklarınıza yönelik ifadeler yer almaktadır. Lütfen her ifadede yer alan stratejileri GEÇEN haftadan BUGÜNE ne kadar yoğun gerçekleştirdiğinize yönelik değerlendirmenizi ilgili yere $\mathrm{X}$ işareti koyarak yapınız.

Birinci Boyut: Çocuklarla pozitif ilişki kurmak $(1,2,3,4)$

İkinci Boyut: Çocukların isteklerini doyurmak $(5,6,7)$

Üçüncü Boyut: Çocuklarla oyun oynamak $(8,9,10,11,12)$

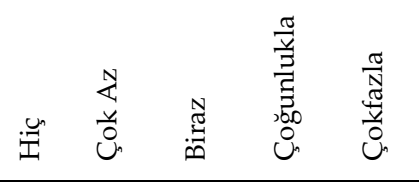

1- Öğrencilerimi mutlu etmek için; onlara güzel sözler söyledim.

2- Öğrencilerimi mutlu etmek için benim için değerli olduklarını hissettirdim.

3- Öğrencilerimi mutlu etmek için; onlara sınıf içinde övücü konuşmalar yaptım.

4- Öğrencilerimi mutlu etmek için; onlara kulak verdim.

5- Öğrencilerimi mutlu etmek için; zaman zaman sürprizler yaptım.

6- Öğrencilerimi mutlu etmek için; onlara hitap eden etkinlik yaptım.

7- Öğrencilerimi mutlu etmek için; onların sevdiği kurabiyeleri ve tatılıarı verdim.

8- Öğrencilerimi mutlu etmek için; sevdiği oyunları onlarla birlikte oynadım.

9- Öğrencilerimi mutlu etmek için; onların sevdiği oyunları oynattım.

10- Öğrencilerimi mutlu etmek için; onların oyun aktivitelerine katıldım

11- Öğrencilerimi mutlu etmek için; onlarla dans ettim.

12- Öğrencilerimi mutlu etmek için; müzikli etkinlikler hazırladım. 